\title{
Glossary of Key Terms Appearing in the Book
}

Anti-proverb: An intentionally changed (distorted, twisted, parodied) proverb with a new meaning and often a humorous or satirical effect, including the possibility of becoming a new proverb.

Aphorism: A literary form like the proverb in its straightforward memorable formulation as in Art is long, life short.

Asyndetic coordination: The linking of conjoins without the use of coordinators.

Binomial: Fixed combination of two words linked by a conjunction, usually by and, and occasionally by or (e.g. law and order, sooner or later, live and learn, sink or swim, by and by.); the combination of three words (trinominals) can also be found (e.g. Tom, Dick and Harry; lock, stock, and barrel).

Catch-phrase: (also called 'winged words') Popular phrase that is connected with a person (for example, a politician, entertainer, literary character) who used it and made it famous (e.g. Speak softly and carry a big stick -Theodore Roosevelt).

Categorization: Categorization is a bit more than mechanical classification according to different themes. Proverbs can be classified in many ways and ordering things tells always about your preferences. Categorization refers to a more scientific approach than classification for popular proverb collections. It means that the one who categorizes proverbs has deep knowledge of this genre of folklore and language. These professionals have generally massive material to categorize and basic concepts and/or a theory structuring their plan. Categorization is based on (ethnologic, linguistic, social psychological) concepts and knowledge in advance of the material to be categorized.

Citation: A larger text sample that contains the search word.

Classical theory of features: The members of the category all share the same features; all category members have an equal status, and sharp and rigid boundaries, in terms of necessary and sufficient conditions. Applying it to proverbs, all proverbs have the same features.

Clefting: Re-arranging the basic word order of an unmarked sentence, and fronting constituents, such as nouns, adverbs, and adjectives, to sentence initial position.

Cliché: Sentence like proverb in terms of forming a complete utterance, but lacking its traditionality and imagery: The cliché expresses a trite observation as in Boys 
will be boys. In paremiology, analytical clichés, which can have only a concrete and direct overall meaning (regardless of the possible presence of figures and tropes on the lexical level) and which do not ask for some extended interpretation, are distinguished from synthetic clichés, which are assumed to have an extended (transferred, figurative) overall meaning.

Cognitive Concept: Cognitive concepts are the cognitive (mental) structures in the mind which represent the outer world mentally and therefore structure our thoughts (and linguistic actions).

Collocation: The frequent and habitual co-occurrence of words in a language (e.g. $a$ hard frost [ ${ }^{*}$ a strong frost], gain experience [ ${ }^{*}$ make experience]).

Collocation analysis: Automatic method that calculates which words co-occur more often than would be expected by chance. There are several different algorithms for collocation analysis.

Comparative approach: This approach aims at showing and discussing the similarities between pairs of proverbs or groups of proverb texts in one language, but more often in two or more languages. In the latter case it is often used interchangeably with the term crosscultural study of proverbs.

Conceptual Metaphor Theory: Revolutionary thesis by George Lakoff and Mark Johnson (see Metaphors we live by). Due to this thesis "metaphor is pervasive in everyday life, not just in language but in thought and action. Our ordinary conceptual system [...] is fundamentally metaphorical in nature” (Lakoff \& Johnson, 1992: 3;.) ${ }^{203}$. This new cognitivist approach is centred on the "metaphorical concept", usually abbreviated as MC.

Concordance: List of words used in a text, with their immediate contexts. A concordance can be used to show language patterns.

Connotation: Connotation or connotative meaning is additional, or secondary, meaning of a word or an expression, which accompanies its basic (denotative, referential) meaning and adds personal or emotional associations like for instance appraisal or assessment. The connotative meaning of a language utterance is only explicable in context.

203 Lakoff, G. \& Johnson, M. (1992). Metaphors We Live By. Edition 9 [print.]. Chicago [u.a.]: Univ. of Chicago Press. 
Contrastive approach: Comparing proverbs in two or more languages synchronically or panchronically. This approach aims at explicating the differences between a pair of proverbs, or a selection of proverb texts in two or more languages in relation to a common frame of reference or agreed-upon criterion (tertium comparationis).

Core set of proverbs: Sample of proverbs which is designated for paremiological experiments and is based on the expert's analysis of dictionaries, proverb collections, texts and direct long term observation of spoken communication.

Corpus: A collection of written or spoken texts; the corpus data is digitalized i.e. machine readable and saved on a computer. In addition to the text data itself, corpora can also contain metadata, which describe the data, and linguistic annotations (see Lemnitzer \& Zinsmeister, 2010: 8) ${ }^{204}$.

Counter-proverb: An overt negation or sententious-sounding rebuttal of a proverb, and explicit denial of the proverb's asserted truth, with the chance of becoming a proverb in its own right, like e.g. Flattery will get you everywhere (versus the older Flattery will get you nowhere.).

Cultureme: An axiologically marked entity or content, explicated through a semantic transformation of the question-answer kind, e.g.: What does this linguistic item affirm (i.e., praise, recommend, approve of, justify, etc.) / deny (i.e., condemn, criticise, disapprove of, ridicule, etc.)? A cultureme is represented by a noun or a noun phrase. Concerning proverbs, simple examples of culturemes are knowledge $(+)$ for the proverb Knowledge is power and haste (-) for Haste makes waste.

Elocutio: The term has originally been used in classical rhetoric for describing the style or manner of speaking, especially in public. In linguistics, elocution refers to the manner of composing a text according to the intention and situation.

Empirical paremiology: Research of knowledge and familiarity of proverbs based on demographic research, psycholinguistic experiments and an extensive analysis of huge corpora. Whereas earlier research in this direction focused predominantly on the question of proverb minima, i.e. on the question which proverbs are known by "all" members of a given culture or society, contemporary empirical paremiology, in a broader understanding of this concept, studies which proverbs of a given culture are known in which verbal form(s) by which members of the given society, and which

204 Lemnitzer, L. \& Zinsmeister, H. (2010). Korpuslinguistik: Eine Einführung. 2. durchges. und aktualisierte Aufl. (Narr Studienbücher). Tübingen: Narr. 
collective overlaps and intersections exist with regard to proverb knowledge and familiarity.

Entailment relationships between metaphors: "The metaphorical concepts Time is money, Time is a resource, and Time is a valuable commodity form a single system based on subcategorization, since in our society money is a limited resource and limited resources are valuable commodities (...). Time is money entails that Time is a limited resource, which entails that Time is a valuable commodity" (Lakoff \& Johnson, 1992: 9, $)^{205}$.

Epigram: A short poem, often featuring some ironic or surprising turn (a wasp with a sting). Typically, as the term implies, an epigram is imagined by the reader to be written - in contrast to a lyric poem, imagined to be sung (as to the accompaniment of a lyre).

Epistemology: The theory of knowledge, especially with regard to its methods, validity, and scope, and the distinction between justified belief and opinion (Oxford Dictionary $)^{206}$.

False friend: Words and expressions that seem similar in two languages, but have different meanings.

Formula (also called routine formula): Conventionalized utterance used in recurrent situations (e.g. Many happy returns of the day; Fair nough).

Generalised proverb type: Some group titles in Matti Kuusi's international typesystem of proverbs are like proverbs themselves. Generalised proverb types can also be called moulds of proverbs. The word 'mould' refers to the process of creating new proverbs or anti-proverbs. The question is about an attractive and effective structure or pair of words that produces several new innovations. This is not a new phenomenon but a central way for people to develop expressions.

Hapax/nonce proverb: A modified proverb that is context bound and/or often lacks imagery and has little aesthetic value and impact potential.

205 Lakoff, G. \& Johnson, M. (1992). Metaphors We Live By. Edition 9 [print]. Chicago [u.a.]: Univ. of Chicago Press.

206 http://www.oxforddictionaries.com/definition/english/epistemology. 
Homonyms: Words having identical graphemic and phonemic representation, but have different meanings, e.g. cut (to separate with or as if with an instrument) and cut (a wound made by cutting).

Illocutionary act: In pragmatics, the term stands for the actual purpose of a speech act or in other words, for the intention of the speaker to perform a communicative effect on the reader/listener.

Incongruity: Violation of expectation.

KWIC (Key Word In Context): One line of a computer-generated concordance. The search word is in the centre and some context words are shown left and right.

L1 (First Language / Language 1): A person's native language.

L2 (Second Language / Language 2): A person's second language.

Lingua franca: Any language that is widely used as a means of communication among speakers of other languages, for example, Latin in the Middle Ages, Russian in Eastern Europe, or English throughout the world today.

Linguistic concept: A discrete unit of cognition and the mental lexicon, expressed in the lexemes and gramemes of the natural languages. When human beings think, they use concepts. Concepts underlie notions.

Linguocultural concept: A unit of knowledge and conscience shared by a large group of people who speak the same language, which has a fixed linguistic form (expression) and is marked by distinct ethnocultural specifics.

Loan translation: The direct translation of a word or expression like a proverb and its acceptance from the original language into the target language.

Logeme: The summarized, generalized basic meaning of a group of similar, thematically close proverbs. For example, the English proverbs Actions speak louder than words, An ounce of practice is worth a pound of precept, Example is better than precept, and Deeds will show themselves, and words will pass away are subsumed under the single logeme Speaking is less efficient than doing.

Maxim: Like the proverb in forming a complete utterance, but lacking its traditionality and imagery. The maxim states a rule for conduct as in Never put off till tomorrow what you can do today. 
Metacommunication: Communication about communication; the use of words and wordgroups (e.g. proverbial; so to speak) or typographic means (e.g. inverted commas; italics) to mark or introduce linguistic units (such as proverbs) in order to guarantee communicative adequacy.

Meta-language: Language about language, the language which is spoken about being called an 'object language'. Meta-language is an important issue for paremiology, particularly when a proverb’s meaning is to be described.

Ornatus: Ornatus is a technical rhetorical term, meaning rhetorical decoration. It refers to the intentional deviation from the (conventional) norms by using rhetorical figures and tropes.

Outer access structure: Structure specified for accessing the dictionary articles in a word (lemma) list, with regard to proverb dictionaries, to find a proverb or keyword article in the proverb or keyword list of a dictionary depending on the arrangement of proverbs.

Parataxis: This term refers to the linking of constructions of the same grammatical and semantic level through juxtaposition or punctuation, instead of using formal, either coordinating conjunctions (for, and, nor, but, or, yet, so) or subordinating conjunctions (although, because, since, unless).

Paremiological competence: The active and the passive knowledge of proverbs by an individual in a paremiological experiment.

Paremiological experiment: Prescriptive (passive) or descriptive (active) test to examine the paremiological competence of informants.

Paremiological minimum: 1. A set of proverbs that all members of society know; 2 . A set of proverbs that an average adult is expected to know or is to be familiar with; 3 . A set of proverbs based on empirical sociolinguistic research that a specific group of informants knows or is familiar with.

Paremiological optimum: A correlated set of the best known proverbs among speakers and the most frequent proverbs in huge corpora.

Paremiological performance: The active and the passive overall knowledge of proverbs by all informants who took part in a paremiological experiment.

Paremiology: The study of proverbs. 
Perlocutionary act: In pragmatics, the term stands for obtaining an effect, which goes beyond the illocutionary act, e.g. persuasion, making angry or insecure, hurting, consoling, praising etc.

Phrasal verb: A combination of a verb and (particle(s) or preposition(s). It forms a single unit of meaning (e.g. put up with = 'tolerate').

Phraseodidactics: Discipline dealing with the teaching of phraseological units in language instruction.

Phraseology: (1) Set of phraseological units (phrasicon); (2) Field of study investigating these units.

Phrasicon: The set of phraseological units in the lexicon of a language community.

Polygenesis: Assumption that expressions have not only one, but multiple origins. More precisely, that at least a few proverbs might have originated independently from each other in a number of languages at different times and places.

Pragmatics: Subfield of linguistics that examines the usage of utterances in concrete communicative situations and describes which kinds of speech acts are performed by a speaker. As a semiotic dimension pragmatics focuses on the relation of signs to interpreters. More specifically, pragmatics is that portion of semiotic which deals with the origin, uses, and effects of signs within the behavior in which they occur.

Polysemous word: A word having two or more meanings.

Prototype theory: Members of the category are different, with fuzzy boundaries, better and worse examples, and prototype effects. Applied to proverbs, not all proverbs share the same features, there are better and worse examples for proverbs.

Proverb citation: One type of lexicographic examples, authentic excerpted text extracts containing proverbs, exemplifying their meaning and usage, supplied with an abbreviation of the citation source.

Proverb clustering: Insertion of two or more proverbs (standard or modified) into a non-proverb context, resulting in a blend of proverb and non-proverb texts.

Proverb collage: An entire text or its structural part(s) composed of proverbs (standard or modified) and/or sometimes other easily recognized elements, like familiar quotations, proper names, phraseologisms. 
Proverb concept (usually abbreviated as PC): According to Lewandowska (Lewandowska, 2008 ${ }^{207}$ proverb concepts are cognitive concepts, comparable to Lakoff \& Johnson's metaphorical concepts. These PCs not only pre-structure our thoughts and actions like metaphors do, but at the same time they put linguistically catchy words into our mouth.

Proverb equivalence: Sameness of the lexis, structure and meaning of pairs or groups of proverbs in two or more languages, e.g., Hurry slowly (English), Eile mit Weile [Hurry slowly] (German), Festina lente [Hurry slowly] (Latin).

Proverb keyword: First or most meaningful component of proverbs, generally the first noun, adjective or adverb.

Proverb modification: Creative deformation of a proverb affecting its structure and/ or semantics.

Proverb-poem: A poem that has as a principal focus on one or more proverbs, quoted or alluded to, which the reader is assumed to be familiar with.

Proverb system: The entire body of proverbs in a language. As members of a system the proverbs in a language display systemic relations, e.g., syntagmatic, paradigmatic, synonymy, antonymy, etc.

Proverb type: The concept referring to the Matti Kuusi international classification of proverbs, where it presupposes a concrete proverb title or a cluster of proverbs having the common idea, and including proverb variants.

Proverbial comparison: Fixed traditional phrase with as, like or than, e.g. as brown as a berry, like a house afire and older than the hills.

Proverbial phrase: A traditional, characteristically figurative form, which cannot stand on its own, for example to kick over the traces, which lacks a subject.

Proverbial simile: see Simile

Proverbiality: Having the necessary characteristics of a proverb, that is, currency and traditionality, as well as numerous structural (formula, parallelism) and poetic (alliteration, rhyme) markers.

207 Lewandowska, A. (2008). Sprichwort-Gebrauch heute. Ein interkulturell-kontrastiver Vergleich von Sprichwörtern anhand polnischer und deutscher Printmedien. Bern: Peter Lang. 
Pseudo-proverb: A proverb-like statement invented to resemble a proverb (having traditional stylistic markers and based on a paremic structural-semantic model) that may, if repeated over time, become a new proverb.

Semantics: A semiotic dimension which concentrates on the relations of signs to the objects to which the signs are applicable, dealing with the signification of signs in all modes of signifying. Paremiological semantics focuses on the study of how proverb meaning is generated and how it can be described.

Semiotics: A branch of science which studies signs, or sign systems, and the processes of sign generation (semiosis) and usage. The discipline of semiotics is usually subdivided into the three semiotic dimensions of pragmatics, syntactics, and semantics. Semiotic paremiology studies the proverb in (at least one of) these aspects from a semiotic perspective, in its semiotic aspects.

Sign: The representation of an object, or a notion (concept), that implies a connection between itself and that object. A sign tends to be regarded either as being part of a sign system, in which a sign is different in at least one aspect from all other signs of that system, or as the result of some sign generating process. In addition to simple signs, one also speaks of super-signs, i.e. complex signs, or sign complexes. In addition to the denotative function of a sign it may also be seen to include/generate (additional) connotative meaning structures. In paremiology, a proverb may be seen to be a super-sign, generated on the basis of more than one simple sign, and it may also be seen as one complex sign.

Simile (also called stereotyped comparison): Set phrase that compares something to something else, using the words like or and (e.g. as clear as crystal, sleep like a log).

Slogan: Non-traditional formulaic unit created to promote a product or idea as in Nike's advertising slogan Just do it or Obama's campaign slogan Yes, we can.

Speech act: An utterance which has some performative function in language and communication. Often, a distinction is made between direct speech acts, when a speaker utters a sentence and means exactly and literally what s/he says, and indirect speech acts, when a speaker also utters a sentence, and means what s/he says, but additionally means something more, or something different instead. More precisely, it is when the speaker communicates to the hearer more than he actually says by way of relying on their mutually shared background information, both linguistic and nonlinguistic, together with the general powers of rationality and inference on the part of the hearer.

Standard use of proverbs: Application of a proverb in its dictionary form. 
Stylistics: Subfield of linguistics, the study of linguistic styles, the way of writing/ speaking and the conventions of language use. The contemporary stylistics describes style as a function- and situation oriented language use.

Syndetic coordination: The explicit linking of conjoins using coordinators such as and, or, and but.

Syntactics: A semiotic dimension which is directed towards the formal relations of signs to one another and which studies the way in which signs of various classes are combined to form compound signs. Syntactics thus is broader than the linguistic study of syntax, and it may concentrate both on the formation of complex super signs and on the combination of a given sign with other signs. Paremiological syntactics may comprise both the study of the syntactical formation of proverbs as super signs from individual signs, or of the relation of proverbs as (super) signs with other (proverbial) signs.

Syntactic parallelism: A rhetorical device used for the purpose of emphasis or foregrounding. It involves the contiguous juxtaposition of syntactically parallel elements of the proverb text - individual lexical items, phrases, clauses, or sentences - for the purpose of suggesting analogical relationships or comparisons.

Tertium comparationis: A common, invariable frame of reference or agreed-upon criterion in relation to which linguistic items are compared or contrasted, e.g., syntactic pattern, logical type, image, main idea, proverb meaning, general concept, logeme, cultureme, etc.

Topicalisation: Clefting a constituent element into sentence initial position, leaving a gap in the main clause, that it is interpreted as filling (Gregory \& Michaelis 2001:1665) $)^{208}$.

Traditionality: Having achieved the status of being known and used over a period of time, usually in variants and different contexts.

Variants of proverbs: Specific verbal variations, belonging to one and the same given proverb type.

Wellerism: A type of proverb-international in its occurrence and many centuries old - that consists of a very short saying (a cliché, proverb, or other brief quotation)

208 Gregory, M. L. and Michaelis, L.A. (2001). Topicalization and Left Dislocation: A Functional Opposition Revisited. Journal of Pragmatics, 33, 1665-1706. 
followed by the designation of a figure to whom the saying is speciously attributed (often the old woman or the devil or the monkey) and then, frequently, by a brief statement of an action or circumstance in which the designated speaker utters the attributed saying. A wellerism is usually intended humorously. Example: "Two heads are better than one," as the cabbage-head said to the lawyer. The name derives from the character Sam Weller in Charles Dickens' novel The Pickwick Papers.

Winged word: see Catch phrase. 